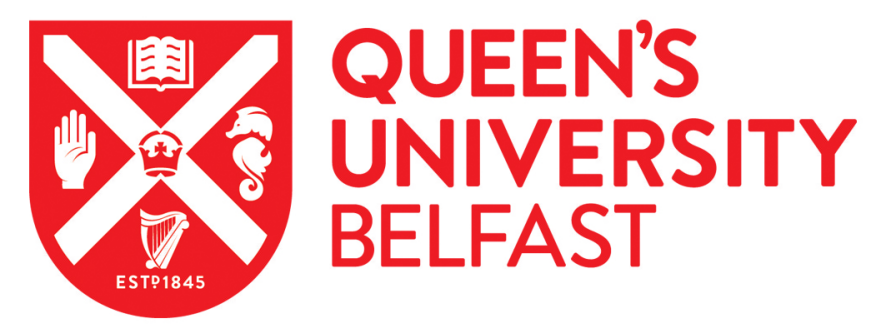

\title{
Distal tephrochronology in volcanic regions: Challenges and insights from Kamchatkan lake sediments
}

Plunkett, G., Coulter, S. E., Ponomareva, V. V., Blaauw, M., Klimaschewski, A., \& Hammarlund, D. (2015). Distal tephrochronology in volcanic regions: Challenges and insights from Kamchatkan lake sediments. Global and Planetary Change, 134, 26-40. https://doi.org/10.1016/j.gloplacha.2015.04.006

Published in:

Global and Planetary Change

Document Version:

Early version, also known as pre-print

Queen's University Belfast - Research Portal:

Link to publication record in Queen's University Belfast Research Portal

Publisher rights

Copyright 2015 The Author(s)

\section{General rights}

Copyright for the publications made accessible via the Queen's University Belfast Research Portal is retained by the author(s) and / or other copyright owners and it is a condition of accessing these publications that users recognise and abide by the legal requirements associated with these rights.

Take down policy

The Research Portal is Queen's institutional repository that provides access to Queen's research output. Every effort has been made to ensure that content in the Research Portal does not infringe any person's rights, or applicable UK laws. If you discover content in the Research Portal that you believe breaches copyright or violates any law, please contact openaccess@qub.ac.uk. 
1 Distal tephrochronology in volcanic regions: challenges and insights from Kamchatkan lake

2 sediments

3 Gill Plunkett ${ }^{1 *}$, Sarah E. Coulter ${ }^{1}$, Vera V. Ponomareva ${ }^{2}$, Maarten Blaauw ${ }^{1}$, Andrea Klimaschewski ${ }^{1}$ \&

4 Dan Hammarlund ${ }^{3}$

5

$6{ }^{1}$ School of Geography, Archaeology and Palaeoecology, Queen's University Belfast, Belfast, Northern

7 Ireland, UK

$8 \quad{ }^{2}$ Institute of Volcanology and Seismology, Petropavlovsk-Kamchatsky, Russia

$9{ }^{3}$ Quaternary Sciences, Department of Geology, Lund University, Sölvegatan 12, SE-223 62 Lund,

10 Sweden

$11 *^{*}$ Corresponding author: g.plunkett@qub.ac.uk

12

13 
Abstract

Kamchatka is one of the world's most active volcanic regions and has hosted many explosive eruptions during the Holocene. These eruptions had the potential to disperse tephra over wide areas, forming time-synchronous markers wherever those tephras are found. Recent research in Kamchatka has begun to focus on the geochemical analysis of individual glass shards in order to characterise tephra layers. We have applied this approach to the study of visible tephras from three lakes - one in central and two in northern Kamchatka - with the aim of identifying key tephras and potential issues in the application of distal (>100 km from an active volcano) tephra in volcanically complex regions. In total, 23 tephras from 22 tephra beds have been geochemically analysed, representing products from at least four volcanic systems in Kamchatka. We demonstrate that distal lake sediments in the region can yield reliable tephrostratigraphies, capturing tephra from eruptions that have the greatest potential to disperse volcanic ash beyond the region. We draw attention to issues relating to correlating and distinguishing key marker horizons from the highly active Shiveluch Volcano, namely the need to ensure inter-lab comparability of geochemical data and good chronological control of the proximal and distal tephras. Importantly, we have also extended the known distribution of two key tephra isochrons from the Ksudach volcano. Our work contributes valuable glass geochemical on data several key marker beds that will facilitate future tephra and palaeoenvironmental research within and beyond Kamchatka. 
Tephrochronology is a well-established technique for reconstructing volcanic histories and dating past environmental change. Proximal tephrochronology in areas close to volcanic sources has traditionally focused on characterising the morphology, whole rock geochemistry and mineralogy of visible tephra beds, and mapping their extent (e.g. Thorarinsson, 1967; Braitseva et al., 1997). Increasingly, characterisation of the glass component is becoming standard practice in volcanic regions (e.g. Larsen, 1981; Gehrels et al., 2006; Fontijn et al., 2014), opening up opportunities to extend the reach of tephrochronology well beyond the confines of the immediate tephra fallout zone. In more distal locations (100s-1000s km), visible or microscopic tephra horizons comprise ash beds that cannot usually be identified reliably by their petrological or morphological features but instead rely on the geochemical characterisation of the glass, the tephra component that is most widely dispersed. Although applied principally as a dating method, distal tephrochronology also enables the extent of volcanic ash dispersal and the possible environmental, economic and societal impact of given eruptions to be assessed (Lane et al., 2013; Jensen et al., 2014; Sun et al., 2014). The distal tephra record is essentially biased towards eruptions that were sufficiently powerful to disperse ash over long distances, but can nevertheless capture events that have not been documented or preserved in the proximal record (de Fontaine et al., 2007; Payne et al., 2008). This paper describes the analysis of distal tephras in three lakes in Kamchatka (western Beringia) as an aid to dating the lakes' Holocene sediment sequences and as a means of assessing the value and challenges of integrating distal and proximal tephra records in a highly active volcanic region. A detailed tephrostratigraphical framework for Kamchatka has previously been established on the basis of extensive visible tephra layers, all of which derive from Kamchatkan volcanic systems (e.g. Braitseva et al., 1992; 1997; Ponomareva et al., 2007). Visible Kamchatkan tephra beds have aided the dating of palaeoenvironmental change on the Peninsula (e.g. Savoskul \& Zech, 1997; Bäumler \& 
Zech, 2000; Dirksen et al., 2013) and centimetre-thick ash beds have been identified in sedimentary sequences from the Sea of Okhotsk (Gorbarenko et al., 2002; Derkachev et al., 2012), the Asian mainland (Melekestsev et al., 1991; Ponomareva et al., 2013b ), the Kuril Islands to the south of Kamchatka (Hasegawa et al., 2011; Kyle et al., 2011), the western Aleutian islands (Kyle et al., 2011), the Bering Sea (Ponomareva et al., 2013a; in press) and the NW Pacific Ocean (Cao et al., 1995). The first comprehensive attempt to characterise glass chemistries from major Holocene marker beds was published by Kyle et al. (2011). An extensive programme of electron probe microanalysis (EPMA) of 88 proximal Late Pleistocene and Holocene tephras from Shiveluch Volcano, northern Kamchatka, one of the region's most active volcanoes, has recently enabled the successful correlation of previously unattributed distal tephras from a variety of terrestrial and marine locations in and around Kamchatka (Ponomareva et al., in press).

Previous attempts to use tephrochronology to date lake sediments in volcanic regions have met with varying success. Significant downward movement of tephra through soft lake sediment has been observed in North American lakes, whereby tephra sank by as much as $1 \mathrm{~m}$ below the contemporary sediment surface through density settling and in some instances formed continuous secondary horizons that could be mistaken for primary ashfall beds (Anderson et al., 1984; Beierle \& Bond, 2013). Dirksen et al. (2011) found fewer tephras represented in lake sequences than in adjacent terrestrial sediments in north-central Kamchatka and concluded that the lacustrine environment provided less favourable preservation conditions than onshore sites. Here too, there was evidence for downward penetration of tephras as a result of density settling, although this was accompanied by an incoherent tephrostratigraphy. In other volcanic regions, however, robust tephrostratigraphies have been recorded in lake systems (e.g. Eden \& Frogatt, 1996; Newton et al., 2005; Wulf et al., 2008). Spatial patchiness was observed in tephra distribution in multiple sections from Svínavatn Lake, Iceland, likely reflecting synoptic weather patterns and their impact on the lake system during the eruptions (Boygle, 1999) and indicating that a single lake core might not fully capture a complete 
tephrostratigraphy for a region. In Paradox Lake, Alaska, located close to several volcanic sources, considerably more tephra horizons were identified in the lake sediment than in terrestrial profiles in the area (de Fontaine et al., 2007). In this instance, the authors conclude that the higher frequency record owed much to the suitability of the lake basin for tephra deposition and preservation.

We examine tephra records from three lakes in central and northern Kamchatka located 160-300 km from Shiveluch Volcano. Ash from several major Holocene eruptions has reached central Kamchatka, mainly from volcanic systems to the south, including Ksudach, Opala, and Khangar, although a number of Shiveluch deposits have also been identified (Fig. 1; Pevzner, 2011). The northernmost site from which a detailed, geochemically-supported tephrostratigraphy is published is Uka Bog $\left(57^{\circ} 49^{\prime} \mathrm{N}, 162^{\circ} 10^{\prime} \mathrm{E}\right)$, where nine tephras from Shiveluch, Ksudach, Khangar and Bezymianny were identified (Dirksen et al., 2011; Kyle et al., 2011). The main events represented in the vicinity of the sampling sites considered in this paper are described below. In addition, there are tephras present in both areas from less well-studied eruptions, but their glass compositions have not been determined.

In our study in central and northern Kamchatka, visible tephra beds form the basis for site tephrostratigraphies, most of which we geochemically characterise using EPMA. Using geochemical comparisons, ${ }^{14} \mathrm{C}$ dating and age-modelling, we evaluate the potential and limitations of applying distal tephrochronology in this volcanically complex area.

\subsection{Principle Holocene tephras in the central and northern Kamchatka}

Ksudach volcano is a shield-like stratovolcano in southern Kamchatka that features several overlapping calderas formed by a series of major eruptions since the end of the Last Glacial period. Two Ksudach eruptions are known in the early mid-Holocene (Braitseva et al., 1992; 1997; Volynets 
et al., 1999). The earlier and smaller event, $\mathrm{KS}_{3}$, erupted a tephra with dacitic glass at $6386 \pm 36 \mathrm{BP}$

112 (7420-7255 cal BP) that has been identified only to the immediate west of the volcano (Zaretskaya et al. 2007; Kyle et al., 2011). The $\mathrm{KS}_{2}$ event produced an ash with a rhyolitic to andesitic glass that dispersed northwards and was recorded as centimetre-thick visible beds in central Kamchatka (Kyle et al., 2011). It has been dated to $6007 \pm 38 \mathrm{BP}(6950-6740 \mathrm{cal} \mathrm{BP})$ on the basis of five combined ${ }^{14} \mathrm{C}$ determinations from soils and peat buried by the ash (Braitseva et al., 1997), but new $A M S{ }^{14} \mathrm{C}$ dates from associated plant macrofossils suggest that this date is too young (F. Pendea, pers. comm.). The $\mathrm{KS}_{1}$ event was the largest Holocene eruption of Ksudach and its tephra extends to northern Kamchatka, rendering it one of the most important isochrons in the region (Braitseva et al., 1997). Fifteen combined ${ }^{14} \mathrm{C}$ determinations have yielded a weighted mean date of $1806 \pm 16 \mathrm{BP}(1820-1700$ cal BP) for this event. Khangar volcano, in the Sredinny Range, consists of a large crater formed by a sub-caldera eruption in the mid-Holocene. Two closely-spaced events are thought to have occurred at ca. $6900 \mathrm{BP}$ $\left(\mathrm{KHG}_{6900}\right)$ and ca. $6600 \mathrm{BP}\left(\mathrm{KHG}_{6600}\right)$, respectively (Bazanova and Pevzner, 2001). The larger of the two events, $\mathrm{KHG}_{6900}$, erupted tephra to the northeast, and visible beds have been identified in northern Kamchatka (e.g. Dirksen et al., 2013). The event has been dated to $6957 \pm 30$ BP (7920-7690 cal BP; Braitseva et al., 1997) or 6872 \pm 38 BP (7795-7620 cal BP; Bazanova and Pevzner, 2001) on the basis of combined ${ }^{14} \mathrm{C}$ dates from associated palaeosols. The distribution of $\mathrm{KHG}_{6600}$ is less well understood. On the basis of distinctive glass geochemistry from five proximal (samples 98106, 98032/2, 98032/4, 98121, 99098/2) and two distal (samples 98052/1, KHG) locations, Kyle et al. (2011) reported three distinct populations distinguishable by their $\mathrm{K}_{2} \mathrm{O}$ content, that the authors suggested might represent three eruptive events. 
Opala is a large stratovolcano in southern Kamchatka. A major explosive eruption in the Late Holocene led to the formation of the Baranii Amphitheater crater at the foot of the volcano and produced the voluminous OP tephra that was dispersed to the northeast (Braitseva et al., 1997; Kyle et al., 2011). This tephra forms a key marker horizon in eastern and central Kamchatka, and it has a very distinctive, glass chemistry characterised by high $\mathrm{K}_{2} \mathrm{O}$ and low $\mathrm{FeO}_{\text {total }}$ and $\mathrm{CaO}$ (Kyle et al., 2011). The eruption has been dated to $1478 \pm 18$ BP (1400-1315 cal BP) using the weighted mean of $11{ }^{14} \mathrm{C}$ determinations on buried soils and charcoal (Braitseva et al., 1995; 1997).

The highly active Shiveluch composite volcano, northern Kamchatka, has featured at least 42 large eruptions during the Holocene (Ponomareva et al., 2007; in press). Until recently, only a small number of these tephras had been geochemically analysed, eight of which were considered key markers (Ponomareva et al., 2007). Kyle et al. (2011) presented glass geochemistry for 13 Shiveluch eruptions from the mid-Holocene to the last major eruption in 1964 that included data from medial and distal tephrostratigraphies. More recently, Ponomareva et al. (2015) examined over 200 proximal sections in the area around Shiveluch, and reported 77 events, of which 42 were classified as major. The authors used Bayesian modelling to refine the ages of the tephras, drawing on radiocarbon dates from organic-rich palaeosols, charcoal and wood associated with the tephras. They provide a comprehensive point dataset of glass geochemistry for 77 Holocene layers, most of which demonstrate a mainly silicic composition. The limited compositional variability between many events presents a challenge to the discrimination of the tephras, however, whereby even small analytical error could potentially lead to miscorrelation of a tephra. Furthermore, it remains to be established if proximal geochemical compositions are representative of the full geochemical suite of a given event.

\subsection{Sites and methods}


Sediment sequences were collected in July and August 2005 from three lakes (Pechora, Lifebuoy and Olive-backed [as attributed during coring expedition]) in northern and central Kamchatka (Fig. 2). Pechora $\left(59^{\circ} 17.613^{\prime} \mathrm{N}, 163^{\circ} 07.766^{\prime} \mathrm{E}, 45 \mathrm{~m}\right.$ above sea level [a.s.I.]) and Lifebuoy (59 $06.593^{\prime} \mathrm{N}$, $163^{\circ} 09.141^{\prime} \mathrm{E}, 20 \mathrm{~m}$ a.s.I.) Lakes are the most northern sites in Kamchatka from which tephrostratigraphies have been recorded. They are located on the Pacific coast, $300 \mathrm{~km}$ north of Shiveluch, and within the trajectory of ash-falls from several large Shiveluch eruptions, as well as those of major eruptions of Ksudach Volcano, $900 \mathrm{~km}$ to the south (Braitseva et al., 1997; Kyle et al., 2011). Olive-backed Lake ( $56^{\circ} 12.074^{\prime} \mathrm{N}, 158^{\circ} 51.493^{\prime} \mathrm{E}, 693 \mathrm{~m}$ a.s.I.), in central Kamchatka, is situated within the Sredinny mountain range, $160 \mathrm{~km}$ southwest of Shiveluch, and within a region that received ash-fall from numerous volcanic systems throughout the Kamchatka Peninsula (Pevzner, 2004, 2011). All three lakes are small in size (<300 m diameter, 3-5 m deep); Olive-backed and Lifebuoy lakes are closed systems without inflowing streams or rivers but Pechora has small inlet and outlet streams.

Multiple series of cores (each labelled A, B, etc.) were collected from the centres of the lakes using a $5 \mathrm{~cm}$-diameter Livingston corer (Wright, 1967) operated from a rubber boat. Lithostratigraphies were recorded in the field with respect to depth from surface water level at the coring location. Sediments were wrapped in plastic film and aluminium foil, secured in plastic drain pipes, and stored in cold rooms in Stockholm University (Lifebuoy, Olive-backed) or Queen's University Belfast (Pechora).

Samples for $\mathrm{AMS}^{14} \mathrm{C}$ dating were taken from the base of sediment sequences and were measured in the Radiocarbon Dating Laboratory at Lund University. Terrestrial plant macrofossils, where present, were selected but bulk sediment was otherwise sampled. Subsequently, a series of bulk sediment samples was extracted from each of the records for AMS ${ }^{14} \mathrm{C}$ dating at Queen's University Belfast. 
Initial age-modelling, with reference to tephras identified in the respective lakes, suggested no appreciable offset in the bulk sediment ages of Pechora and Olive-backed Lakes, but a persistent multi-centennial reservoir effect was identified in Lifebuoy Lake (see section 3.2). Additional efforts were therefore made to extract terrestrial plant macrofossils from the Lifebuoy Lake sediment sequence for $\mathrm{AMS}{ }^{14} \mathrm{C}$ dating.

All but two visible tephra layers were subsampled for geochemical analyses from the three lake sites. To corroborate tephrostratigraphical correlations between multiple core sections from individual sites, selected tephras were analysed from multiple cores. Tephra samples were prepared using standard techniques tailored according to the nature of the sediment (preparation methods for each sample are outlined in Supplementary Information). Samples were mounted onto microprobe slides, covered in Buehler EpoxiCure resin. The slides were then ground and polished to expose the surfaces of the tephra shards.

Major element geochemistry of the tephras was analysed using the electron microprobes at Edinburgh (Cameca SX-100) or Queen's University Belfast (JEOL FEGSEM 6500F) (see Supplementary Information for analytical settings). Previous work has shown that these two systems produce comparable data (Coulter et al., 2010). Secondary glass standards Lipari and/or ATho were analysed at each analytical session to ensure that satisfactory operating conditions were achieved (see Supplementary Information for a discussion of instrumental precision). Point analyses with analytical totals $<95 \%$ were rejected (in accordance with recommendations by Hunt \& Hill, 1993), as were any analyses that likely encountered mineral inclusions (indicated by elevated $\mathrm{CaO}, \mathrm{Al}_{2} \mathrm{O}_{3}$, or $\mathrm{FeO}_{\text {total }}-\mathrm{Ti}_{2} \mathrm{O}$ concentrations). Geochemical data were normalised to $100 \%$ and were compared between sites, as well as with published glass data from Kamchatkan eruptions (Ponomareva et al., 2007; 2013a; in press; Kyle et al., 2011). Geochemical biplots have been used to examine visually the degree of 
compositional similarity between potential correlatives, of which the most discriminatory examples have been included in this paper.

The ${ }^{14} \mathrm{C}$ and tephra dates were used to produce age-depth models using Clam version 2.2 (Blaauw, 2010). Only tephras whose identification was beyond doubt were incorporated into the age-models. Dates for the $\mathrm{KS} 1, \mathrm{OP}$ and $\mathrm{KHG}_{6900}$ tephras are based on published estimates from Braitseva et al. (1997); the $\mathrm{KS}_{2}$ age was not included as its published age has been called into question (see section 1.1). Shiveluch tephras provide direct tie-points between Pechora and Lifebuoy sediment records; their ages have been calculated using the Pechora Lake age-model and they have been incorporated into the Lifebuoy Lake age model. ${ }^{14} \mathrm{C}$ dates were calibrated using the Northern Hemisphere calibration curve IntCal13 (Reimer et al., 2013). Sediment surfaces were assumed to be of recent age at the time of core collection (AD 2004 \pm 5 ). Smooth splines were chosen as the age-model, applying a smoothing of 0.1 to obtain more flexible models. Tephra layers $>1 \mathrm{~cm}$ in thickness were excised from the age-depth models as slumps, since they represent abrupt deposition events that interrupted the otherwise smooth sediment accumulation at these sites. All bulk dates from Lifebuoy Lake were rejected due to a persistent offset in age relative to tephra and plant macrofossil-based ${ }^{14} \mathrm{C}$ determinations. One ${ }^{14} \mathrm{C}$ date from the base of the Olive-backed Lake record indicated a clear age reversal relative to three determinations higher up the profile, and was omitted from the age-model. Rejected dates are shown next to the age models. Modelled age estimates (at 95\% level of certainty) for tephras not used in the age model have been rounded outwards to 10 year brackets.

\subsection{Results}

${ }^{14} \mathrm{C}$ determinations are presented in Table 1 . Table 2 describes the tephra beds and their correlations. In total, 22 tephra layers (including one mixed layer) were analysed, all of which were characterised by predominantly rhyolitic to dacitic glass. Their compositions lie within the 
geochemical fields of Shiveluch, Khangar, Ksudach, and Opala volcanoes (Fig. 3). Complete tephra geochemical datasets from each of the sites are provided in Supplementary Data, along with secondary glass standard results. In the following sections, we compare the data to geochemical data from Ponomareva et al. (in press; Shiveluch tephras denoted by "SH unit") and Kyle et al. (2011; all other tephras).

\subsection{Pechora Lake}

Seven visible tephra beds were observed in the Pechora Lake sediment sequence, all of which were sampled for geochemical analyses from the PechB core (Fig. 4; Table 2). In the field, a fine, lightcoloured band recorded as a "possible tephra" was noted in PechC and PechE at depths of $494 \mathrm{~cm}$ and 492.5-494.5 cm, respectively, but was not examined further or sampled for analysis. Towards the bottom of the sequence, two thin layers of tephra - Pech 836 and Pech 832 - have chemistries that fall within the Shiveluch compositional field (tephras from which are indicated by the code SH). Only three analyses were obtained from Pech 832, however, and the dataset is too limited to permit any robust comparisons. The Pechora age model suggests that Pech 836 and Pech 832 date to 9310$9100 \mathrm{cal}$ BP and 9180-8980 cal BP, respectively, but the tephras do not match any reported Shiveluch beds of this age (Fig. 5a-b). The best geochemical matches are with the closely spaced eruptions SH unit 45 ( $\sim 252$ cal BP) and SH unit 44 ( 8188 cal BP) (Ponomareva et al., in press) but the considerably older age estimates for the Pechora tephras suggest that Pech 836 and Pech 832 could be products of other events.

Pech 776-778 comprises a rhyolitic to dacitic glass comparable to products from Ksudach. On the basis of its heterogeneity, Pech 776-778 can be correlated with the $\mathrm{KS}_{2}$ tephra (Fig. 6a-d). In Pechora Lake, this tephra has an age-modelled date of $7350-7180$ cal BP, suggesting that the $\mathrm{KS}_{2}$ eruption occurred several centuries earlier than the currently accepted date (6950-6740 cal BP). 
Pech 768 is an homogenous rhyolitic tephra similar to many products from Shiveluch and has an agemodelled date of 7040-6890 cal BP. Two proximal tephra beds - SH unit 40 ( $6611 \mathrm{cal} \mathrm{BP}$ ) and SH unit 39 ( 6451 cal BP) - fall close to its timeframe (Ponomareva et al., in press), but SH unit 40 is a trachydacitic glass, and $\mathrm{SH}$ unit 39 (previously known as $\mathrm{SH}_{5600}$ ) appears to be distinguishable on the basis of its $\mathrm{Al}_{2} \mathrm{O}_{3}$ to $\mathrm{FeO}_{\text {total }}$ content although the small offset could perhaps be due to analytical error

(Fig. 5c-d). Three thicker tephra beds above Pech 768 are similarly attributable to Shiveluch.

According to the Pechora age model, Pech 746-749 was erupted in the period c. $6390-6260$ cal BP, but it is clearly distinguishable from SH unit 39/ $\mathrm{SH}_{5600}$ ( $6451 \mathrm{cal} \mathrm{BP}$ ) and $\mathrm{SH}$ unit 37 ( 5634 cal BP) tephras by its higher $\mathrm{SiO}_{2}$ and $\mathrm{Al}_{2} \mathrm{O}_{3}$, and lower $\mathrm{CaO}$ content (Figs. 5e-f). No glass geochemical data are available for the intervening SH unit 38. Pech 746-749 most closely resembles SH unit 36 (previously known as $\mathrm{SH}_{4700}$ ) but unit 36 has a substantially younger age estimate ( 5591 cal BP; Ponomareva et al., in press).

Pech 674-676 has an age-modelled date of 5280-4990 cal BP. Reported Shiveluch tephras of this age include SH unit 35 ( 5228 cal BP) and SH unit 34 (SHdv; 4892 cal BP) (Ponomareva et al., in press). $\mathrm{SH}$ unit 35 has a distinctively higher $\mathrm{K}_{2} \mathrm{O}$ content and the rhyolitic component of the bimodal $\mathrm{SH}$ unit 34 has a higher $\mathrm{Al}_{2} \mathrm{O}_{3}$ content, and both can therefore be dismissed as correlatives (Fig. 7a-b). Over a broader timespan, Pech 674-676 compares most closely with SH unit 36/SH 4700 ( 5591 cal BP). Pech 557-559 is a rhyolitic tephra with a single dacitic shard that lies outside the Shiveluch compositional field. The age model places Pech 557-559 at 3980-3690 cal BP. There are several Shiveluch eruptions around this time, but the best geochemical match is with the silicic component of SH unit 29 ( $\sim 4010$ cal BP; Fig. 7c-d). Geochemical data for this unit are based on an ignimbrite deposit, however, and the event has not been associated with wider tephra dispersal. SH unit 32 ( $\sim 158 \mathrm{cal}$ BP) and SH unit 33 ( $\sim 372$ cal BP) are also very similar to Pech 557-559 but SH unit 32 seems to be distinguishable on 
the basis of its $\mathrm{K}_{2} \mathrm{O}$ and $\mathrm{CaO}$ content (Fig. 7d). Other Shiveluch tephras around this time can be differentiated from Pech 557-559 on various oxides.

Seven ${ }^{14} \mathrm{C}$ determinations were obtained on bulk sediment. In view of the uncertain relationships between the Shiveluch tephras in Pechora Lake and published datasets, no tephra ages have been used in the age model (Fig. 4). The modelled age for Pech 674-676 is consistent with a ${ }^{14} \mathrm{C}$ determination from below its counterpart (LB 1061) in Lifebuoy Lake (section 3.2), implying that the Pechora age model is robust at this point. Given the similarities between the Pechora and Lifebuoy Lake tephrostratigraphies, the possible tephra at $494 \mathrm{~cm}$ at Pechora Lake may correspond to, and has a modelled age that is consistent with, the $\mathrm{KS}_{1}$ tephra (section 3.2). The age model indicates moderate (20-38 $\left.\mathrm{yr} \mathrm{cm}^{-1}\right)$ sediment accumulation up until c. 5700 cal BP, followed by a period of rapid accumulation $\left(7-20 \mathrm{y} \mathrm{cm}^{-1}\right)$ until c. $4000 \mathrm{cal} \mathrm{BP}$, and a moderate rate of accumulation (20-35 $\mathrm{yr}$ $\mathrm{cm}^{-1}$ ) thereafter.

\subsection{Lifebuoy Lake}

Eight visible tephras were recorded in the Lifebuoy Lake sediment sequence (Fig. 8; Table 2). Seven of the tephras have rhyolitic geochemical compositions consistent with Shiveluch. The lowermost tephra, LB 1172-1176, is the thickest of the ash beds at this site, and strongly correlates with Pech 746-749 (Fig. 5e-f). LB 1061 similarly compares well with Pech 674-676 (Fig. 7a-b) and LB 906 shows a strong correlation with Pech 557-559 (Fig. 7c-d). The geochemical composition of LB 726 is consistent with that of the $\mathrm{KS}_{1}$ tephra from Ksudach (Fig. 6a-d). Lifebuoy Lake is now the northernmost geochemically-confirmed location of this ash. Two couplets of very thin (3-5 $\mathrm{mm})$ tephras were recorded towards the top of the profile. The chemistries of the three lower tephras most closely resemble several Shiveluch tephras erupted in the last millennium (SH unit 6 to unit 4; 
Ponomareva et al., in press), but their major element compositions are not sufficiently distinct to enable correlations with the recorded events (Fig. 7e-f).

A bulk sediment sample at the level of the LB 726 tephra yielded a ${ }^{14} \mathrm{C}$ determination $\sim 600{ }^{14} \mathrm{C} \mathrm{yr}$ older than the reported age of the $\mathrm{KS}_{1}$ tephra, and called into question the validity of the bulk sediment dates at this site. Two additional dates were then obtained from terrestrial plant macrofossils that confirmed a multi-centennial reservoir effect in the bulk sediments. Consequently, all bulk sediment dates from Lifebuoy Lake were rejected. The ages of the LB 1172-1176, LB 1061 and LB 906 tephras were established on the basis of the age-modelled dates for their correlatives in Pechora Lake (Pech 746-749, Pech 674-676 and Pech 557-559, respectively). These ages, along with the plant macrofossil ${ }^{14} \mathrm{C}$ dates and the $\mathrm{KS}_{1}$ tephra layer, were used to construct an age model for Lifebuoy Lake (Fig. 8). The age model suggests rapid sediment accumulation in the lake $\left(6-14 \mathrm{yr} \mathrm{cm}^{-1}\right)$ from 7680-7200 cal yr BP to present. Modelled ages for the four uppermost tephras range from 710540 cal yr BP for LB 610 to $580-420$ cal yr BP for LB 594, and suggest that one of the layers may correlate with SH unit 5 dating to $\sim 553$ cal BP (Ponomareva et al., in press).

\subsection{Olive-backed Lake}

The main core series from Olive-backed Lake, OB Core A (OBA), contained six visible tephras, five of which were confined to the bottom metre of sediment (Fig. 9; Table 2). Parallel cores OB Core B $(\mathrm{OBB})$ and $\mathrm{OB}$ Core $\mathrm{D}(\mathrm{OBD})$ each contained four tephras, and in $\mathrm{OB}$ Core $\mathrm{D}(\mathrm{OBD})$, seven tephras were visible including three towards the top of the sequence. Recorded depths for the tephras varied between cores, but spacing between the tephras suggested that cross-correlation between the cores on the basis of tephrostratigraphy was possible. These correlations were confirmed by geochemical analyses of selected tephras from two or more core series. The recorded depths of the 
tephras in OBA were taken as primary and were used to designate the tephras, and the relative positions of the parallel core segments were adjusted accordingly.

OB 592.5-594 was analysed using a sample from OBD (OBD 599). The geochemistry indicates a heterogeneous rhyolitic population consistent with tephra from Khangar, southern Kamchatka (Kyle et al., 2011; Fig. 10a-d). OB 592.5-594 contains a mixture of the three KHG populations identified by Kyle et al. (2011), but most closely matches samples from the bottom of pumice lapilli beds to the north and north-northeast of Khangar Volcano (samples 98121 and 98032/2; Kyle et al., 2011). We therefore propose that OB 592.5-594 correlates with the main $\mathrm{KHG}_{6900}$ event. OB 579 (comprising OBA 579 and OBD 586) shares geochemical similarities with the Khangar tephras but is distinguishable by a higher $\mathrm{SiO}_{2}$ and $\mathrm{K}_{2} \mathrm{O}$ and a lower $\mathrm{Al}_{2} \mathrm{O}_{3}$ content (Fig. 10a-d). For the time being, this appears to be an unknown event of uncertain provenance, dating to $7400-7270 \mathrm{cal}$ BP. Its high $\mathrm{K}_{2} \mathrm{O}$ content may indicate a source in the Sredinny range, such as Ichinsky, less than $100 \mathrm{~km}$ to the southwest, which is known to have erupted shortly after the $\mathrm{KHG}_{6600}$ event (Pevzner, 2004; Fig. 1). OB 576 (comprising OBA 575.5 and OBD 583) shows a clear correlation in major element composition with Ksudach tephra $\mathrm{KS}_{2}$ and Pech 776-778 (Fig. 6). In Olive-backed Lake, its modelled age (7300-7160 cal BP) matches that from Pechora Lake (7350-7180 cal BP).

$\mathrm{OB} 563$ is a predominantly rhyolitic tephra with a mixed population distinguishable by $\mathrm{SiO}_{2}-\mathrm{Al}_{2} \mathrm{O}_{3}-$ $\mathrm{FeO}_{\text {total }}-\mathrm{CaO}-\mathrm{K}_{2} \mathrm{O}$ values (Figs 3, 10a-d). The high $\mathrm{SiO}_{2}(>76 \mathrm{wt} \%$ ) population (OB 563a) resembles the KHG tephra, correlating particularly well with Kyle et al.'s (2011) sample 98052/1 (Fig. 10a-d), but it is stratified above the $\mathrm{KS}_{2}$ tephra, and has a modelled age of $6790-6640$ cal BP. The low $\mathrm{SiO}_{2}(<76$ wt\%) population (OB 563b) lies within the Shiveluch compositional field and compares well with SH unit 37 and SH unit 36/SH 4700 (Fig. 5c-d), both of which are, however, younger by approximately a 
millennium (Ponomareva et al., in press). It also correlates strongly with Pech 768, although it has a marginally higher $\mathrm{K}_{2} \mathrm{O}$ content and the modelled ages for the two tephras do not overlap.

OB 542 is an homogenous rhyolitic tephra whose geochemistry resembles those of several Shiveluch eruptives (Fig. 5e-f), especially SH unit 36/SH4700, but its modelled age at Olive-backed Lake (59105690 cal BP) suggests that OB 542 is approximately two centuries older than unit 36, which was, furthermore, dispersed mainly toward the northeast (Ponomareva et al., 2007; Kyle et al. 2011). The tephra is indistinguishable in major element composition from Pech 746-749 and LB 1172-1176, but its dispersal axis (to the SW of Shiveluch) and its age estimate (younger than Pech 746-749) raise the possibility that this is a previously unreported Shiveluch eruption.

OB 383-388 (including OBA 383.5-388 and OBD 417-420) correlates strongly with the $\mathrm{KS}_{1}$ ash (Fig. 6a-d). Olive-backed Lake is located close to the $5 \mathrm{~cm}$ isopach of this tephra (Kyle et al., 2011). OB 383-388 was recorded in the field as a grey tephra and it likely corresponds to the upper layer of pyroclastics deposited at Ksudach during this event (Braitseva et al., 1997). Geochemical analyses indicate that the high-potassium rhyolite OB 369 (comprising OBD 404) correlates with the OP tephra (Fig. 10e-f). OB 369 has a higher $\mathrm{SiO}_{2}$ content than the OP data published by Kyle et al. (2011) which include geochemistry from proximal, medial and distal deposits. Nevertheless, our data fall within the geochemical range of OP tephra recorded within its more westerly distribution in the Sredinny Range (V. Ponomareva and M. Portnyagin, unpublished data), and it seems likely that our data reflect natural variability within the OP glass. A further tephra was recorded in OBD at a depth equivalent to $364 \mathrm{~cm}$, but was not analysed due to time constraints.

The age model for Olive-backed Lake (Fig. 9) includes published ages for the $\mathrm{KHG}_{6900}, \mathrm{KS}_{1}$ and OP tephras. In addition, twelve ${ }^{14} \mathrm{C}$ determinations were obtained, including three from plant 
macrofossils (LuS-6269, LuS-10895 and LuS-10896). LuS-6269 was treated as an outlier as it was significantly younger than the $\mathrm{KHG}_{6900}$ tephra (OB 592.5-594) and two other ${ }^{14} \mathrm{C}$ determinations above it. ${ }^{14} \mathrm{C}$ determinations at the level of the $\mathrm{KS}_{1}$ tephra (OB 383-388) and immediately above the $\mathrm{KHG}_{6900}$ layer (OB 592.5-594) lie within the calibrated age ranges of the tephras. They do, however, appear slightly old relative to the bottom of the slumps associated with these thicker tephras and imply that the tephras may have sunk slightly into the lake sediment. Nevertheless, they indicate that there is no discernible, consistent reservoir affecting the lake sediment at these times. Sediment accumulation rates vary from $48 \mathrm{yr} \mathrm{cm}^{-1}$ towards the base of the core to $19 \mathrm{yr} \mathrm{cm}^{-1}$ towards the top.

\subsection{Discussion}

\subsection{Identification of known tephra isochrons}

Analysis of the distal tephras in this study extends the distribution of two important tephra isochrons to the northern part of Kamchatka. The Ksudach tephras $\mathrm{KS}_{2}$ and $\mathrm{KS}_{1}$ can now be confirmed as visible beds across a distance of over $900 \mathrm{~km}$ from their source, and provide direct linkage between sedimentary records across the Kamchatka Peninsula. This level of precise correlation greatly facilitates the discernment of synchroneity/asynchroneity in palaeoenvironmental changes on a regional basis, and enables the impact of the eruptions and their ash falls on ecosystems to be assessed (e.g. Andrén et al., submitted; Hammarlund et al., submitted). Both tephras have recently been identified in eastern North America (S. Pyne-O'Donnell, pers. comm.; H. MacKay, pers. comm.), indicating potential to scrutinise past environmental changes on an inter-continental basis.

Tephra from the Khangar $\mathrm{KHG}_{6900}$ and Opala OP eruptions has been found at Olive-backed Lake, within the area of their previously mapped distributions. The Olive-backed records supplement the available glass geochemical datasets for these events (Kyle et al., 2011). OB 592.5-594 includes all 
three high and medium $\mathrm{K}_{2} \mathrm{O}$ populations identified by Kyle et al. (2011), demonstrating that the three compositions were erupted more or less simultaneously during the larger Khangar eruption.

\subsection{Shiveluch tephra record}

411

Numerous Shiveluch tephras are recorded in this study, but no robust correlations with glass data from reported events (Kyle et al., 2011; Ponomareva et al., in press) have been possible. Ostensibly, the distal tephras indicate as many as 11 unrecorded Shiveluch eruptions, mostly dispersed towards the northeast. The similarities in the tephrostratigraphies of the two northern lake sites are reinforced by strong geochemical correlation between paired tephra beds, and clearly document three mid-Holocene eruptions during the period in which the two sequences overlap (Fig. 11). Two further events are recorded at Pechora Lake dating to the early Holocene, and four closely spaced Late Holocene events at Lifebuoy Lake are each potential candidates for correlation (geochemically and temporally) with one known Shiveluch eruption (SH unit 5). The greater thicknesses of the tephras in the Pechora sediment sequence (an open lake system) compared to those in Lifebuoy (a closed lake system) likely reflect the inwash of ash from the Pechora catchment. Two Shiveluch tephras are also recorded in the Olive-backed Lake sediment sequence that cannot certainly be correlated with published events of a similar age.

It is conceivable, however, that the correlation of distal tephra to proximal Shiveluch material has been confounded by one or more factors. Geochemical differentiation during the course of the eruptions may not be fully captured by the proximal deposits against which the tephras from this study have been compared. In this respect, it is notable that strong geochemical similarities have been found between tephras in the neighbouring northern lakes, while the OP geochemistry appears to vary geographically. Differences in instrumental calibration and precision may, on the other hand, have added variance to the proximal and distal datasets, giving the impression of poor correlation. 
As secondary glass standards have not been published for the available reference data, we cannot assess the significance of the apparent discrepancies in geochemical composition. Finally, the ages of the published Shiveluch events (Ponomareva et al., in press) have been taken into consideration and in some instances preclude what appear to be suitable geochemical matches (for example, Pech 836 and SH unit 45). Inaccurate age estimates for the proximal or distal tephras (see section 4.3), combined with geochemical subtleties, may therefore mask possible correlations.

With these caveats in mind, we compare the tephrostratigraphies of Pechora and Lifebuoy Lakes to that of Uka Bog, $150 \mathrm{~km}$ to the south (Fig. 11). The Uka sequence closely resembles that of the two northern lakes, insofar as three Shiveluch tephras are recorded between the $\mathrm{KS}_{2}$ and $\mathrm{KS}_{1}$ tephras (Dirksen et al., 2013). The tephras are attributed to $\mathrm{SH}_{5600}$ (SH unit 39), $\mathrm{SH}_{4700}$ (SH unit 36) and $\mathrm{SH}_{3500}$ (now known as SH unit 27), respectively; data from the former two were published by Kyle et al. (2011) and are plotted in Figs 5 and 7. On chronological grounds, the oldest of these three events is generally consistent with the age of Pech 746-749 and LB 1172-1176, but our data are clearly differentiated on several oxides (Fig. 5e-f) from proximal (SH unit 39) and distal ( $\mathrm{SH}_{5600}$ at Uka Bog) tephra from this event (Kyle et al., 2011; Ponomareva et al., in press). The differences cannot easily be explained away as instrumental inaccuracies. Instead, we find a closer correspondence between Pech 768 and $\mathrm{SH}_{5600} / \mathrm{SH}$ unit 39 which, if true, would imply that either the age of Pech 768 is overestimated, or that the age of $\mathrm{SH}_{5600}$ is underestimated. In contrast, the next two tephra beds (represented in Pechora and Lifebuoy Lakes respectively by Pech 746-749/LB 1172-1176 and Pech 674-676/LB 1061) have geochemical signatures that are close to that of $\mathrm{SH}_{4700} / \mathrm{SH}$ unit 36, but once again, the estimated ages are incompatible. Objectively then, it is not possible to determine with certainty that any of the tephras in the lakes correlates with $\mathrm{SH}$ unit 36, as at least two eruptions appear to have produced geochemically indistinguishable glass components as attested by the lake sites. The identity of the $\mathrm{SH}_{4700}$ tephra at Uka Bog is similarly called into question. Finally, a tephra at 
et al., 2013). Pech 557-559 and LB 906 have an age-modelled date (4020-3720 cal BP) that is close to the age of $\mathrm{SH}_{3500} / \mathrm{SH}$ unit 27 ( 3750 cal BP), but their geochemistries do not support such a correlation. Our findings highlight, therefore, several issues relating to the dating and identification of Shiveluch tephras, and demonstrate some of the difficulties in correlating proximal and distal tephras.

\subsection{Issues with ${ }^{14} \mathrm{C}$ dating of Kamchatkan lake sediments}

It has long been recognised that the dating of bulk lake sediment can be significantly affected by "old carbon" that may be present as dissolved inorganic carbon within freshwater systems, giving rise to

a ${ }^{14} \mathrm{C}$ reservoir effect that results in spuriously old dates (Deevey et al., 1954; Olsson, 1979).

Reservoir effects are not restricted to hard water areas, nor are they constant in time, as they can be influenced by a variety of factors including changes in water-atmosphere carbon exchange rates, hydrology or sediment composition (Barnekow et al., 1998; Geyh et al., 1998). Reworked organic material caused by bioturbation or inwash of eroded deposits can also contribute to age reversals in lake sediments (Hammarlund et al., 2003; Blaauw et al., 2011) while downward root penetration, bioturbation or contamination of material in the laboratory, including microbial growth on samples during storage, can lead to younger ages being obtained (Wohlfarth et al., 1998).

Varve chronologies and tephra layers have proven useful methods for examining the reliability of bulk sediment-based ${ }^{14} \mathrm{C}$ chronologies (e.g. MacDonald et al., 1991; Barnekow et al., 1998). In this paper, recognised tephra beds - namely, the $\mathrm{OP}, \mathrm{KS}_{1}$ and $\mathrm{KHG}_{6900}$ layers - provide a first order check on bulk sediment dates. Each of these events has been dated multiple times by different authors often on bulk terrestrial material immediately below, within or above the individual tephras. Individual age estimates commonly have large standard deviations (>100 yr), but "best estimates" have been calculated by combining dates, with the assumption that all age estimates date the same 
event and that a maximum probability can thus be calculated. The result is usually a ${ }^{14} \mathrm{C}$ determination with a narrower uncertainty envelope ( $<50 \mathrm{yr}$ ), although it is acknowledged that bulk sediment dates may be contaminated by younger carbon from downward penetrating rootlets (Zaretskaya et al., 2007). Such an effect may explain why the published age for the $\mathrm{KS}_{2}$ tephra now appears to be too young (see section 1.1). A more sophisticated Bayesian approach has recently been applied for dating Shiveluch tephras, using prior information from multiple, dated tephrostratigraphies to restrain the probable age range of individual beds (Ponomareva et al., in press).

Of the three lakes examined in this paper, only Lifebuoy Lake reveals a clear reservoir effect in its bulk sediment dates. Lifebuoy Lake is situated in a geological setting similar to Pechora Lake, and the reservoir does not evidently stem from groundwater carbon. At present, we cannot identify the source of the reservoir effect at this lake, although its proximity to the sea (c. $100 \mathrm{~m})$, and a potential input of marine carbon by seabirds, may be a factor. To test this hypothesis, we measured the $\delta^{15} \mathrm{~N}$ content of a sample of lake sediment from Lifebuoy Lake and compared it to a sample of sediment of approximately the same age from Pechora Lake. The sediment samples were dried, pulverized in a mortar and pestle, weighed into tin capusles analysed at the ${ }^{14} \mathrm{CHRONO}$ Centre with a Thermo Delta V Elemental Analyser - Isotope Ratio Mass Spectrometer (EA-IRMS) for $\delta^{15} \mathrm{~N}$ with an analytical precision of better than $0.15 \%$. Although both samples showed relatively low $\delta^{15} \mathrm{~N}$ values, the sample from Lifebuoy $(2.48 \%$ ) being only marginally higher than that from Pechora $(1.08 \%$ ), this difference may provide some evidence of seabird organic matter input to the sediments of Lifebuoy Lake. Griffiths et al. (2010) demonstrated that heavily seabird-affected ponds in the Arctic can exhibit $\delta^{15} \mathrm{~N}$ values as high as $>10 \%$. The $\delta^{15} \mathrm{~N}$ levels at Lifebuoy appear to be substantially lower than this, but the diatom record from Lifebuoy Lake indicates an unusually high nutrient status

507 (Solovieva et al., submitted) that supports the hypothesis of marine bird influence on the lake's ${ }^{14} \mathrm{C}$ balance. 
Insofar as can be determined from the lake models of Pechora and Olive-backed Lakes, no reservoir is evident at these sites. At Olive-backed Lake, there is agreement within the $95 \%$ probability bracket between the published ages of the $\mathrm{KHG}_{6900}$ and $\mathrm{KS}_{1}$ tephras and ${ }^{14} \mathrm{C}$ determinations on bulk sediment associated with their tephras at this site (OB 592.5-594 and OB 383-388, respectively), and the bulk sediment dates show no signs of disharmony with the terrestrial plant macrofossil ${ }^{14} \mathrm{C}$ dates. In the absence of robust geochemical correlations with published Shiveluch eruptions, Pechora Lake lacks a direct means of internally checking for a reservoir effect. The modelled age of Pech 674-676-a correlative of LB 1061 - is consistent, however, with the plant macrofossil-based ${ }^{14} \mathrm{C}$ determination below LB 1061. The modelled age for the $\mathrm{KS}_{2}$ tephra at Pechora Lake is also indistinguishable from its modelled age at Olive-backed Lake.

\subsection{Integrity of the Kamchatkan lake tephrostratigraphies}

521 On the whole, the tephrostratigraphies of the three lakes examined in this paper compare well with peat and soil sequences in their respective areas: the main tephras that we might expect to see at these locations within the intervals the lake sequences cover are present, and we extend the known distribution of visible $\mathrm{KS}_{1}$ and $\mathrm{KS}_{2}$ tephra beds $150 \mathrm{~km}$ northwards. Between parallel cores from each of the lake sites, we observe some minor differences in thicknesses of tephras from core to core, that indicate non-uniform deposition. For the finest, millimetre-thick tephras, this sometimes means that they are absent - or invisible - from some cores (for example, OB 369 - the OP tephra - is not evident in core OBA). Similar "patchiness" of tephras within lake systems has been observed also in cryptotephra studies (Mangerud et al., 1984; Davies et al., 2001). Pyne-O’Donnell (2011) determined that tephra concentrations in lakes were strongly influenced by lake catchment size and the presence of inlet streams, and this has been borne out by the recent study of tephra distributions in lakes following the 2011-2012 eruption of Cordón Caulle, Chile (Bertrand et al., 2014). Inflowing streams are therefore likely to explain the greater thicknesses of tephras in Pechora Lake when 
compared to Lifebuoy Lake, but it is interesting to note the similarities between the two tephrostratigraphies that suggests that the lakes captured and recorded the main ashfall events in this part of northern Kamchatka.

Notwithstanding concerns about the reliability of bulk sediment-based ${ }^{14} \mathrm{C}$ dates, we find little evidence to suggest the tephras in this study sank substantially into sediment. Discrepancies in the recorded depths of individual tephras between parallel cores is more plausibly explained by human error during the coring process as the spacing between tephras remains consistent from core to core. Furthermore, dates for the attributed tephras reveal no discrepancies with the lakes' agemodels. Within the age models, however, ${ }^{14} \mathrm{C}$ determinations relating to the $\mathrm{KS}_{1}$ and $\mathrm{KHG}_{6900}$ tephras in Lifebuoy and Olive-backed Lakes, respectively, fit better with the surface level of these tephras, suggesting potential settling of tephras into "older" surface sediment.

\subsection{Conclusions}

We have analysed 22 tephra beds from three lake sediment sequences in northern and central Kamchatka to evaluate the potential of distal tephrochronology in a volcanically active area. All three lakes lie within $300 \mathrm{~km}$ of one of Kamchatka's most active volcanoes, Shiveluch, and contain multiple tephras attributable to this volcano. Other tephra beds from more southerly volcanic systems are also recorded, providing robust linkages between the lake sites and other palaeoenvironmental sequences across the Kamchatka Peninsula. Our datasets enhance the characterisation of several key marker beds - the $\mathrm{KHG}_{6900}, \mathrm{KS}_{2}, \mathrm{KS}_{1}$ and OP tephras - and will facilitate the identification of these isochrons in future studies. The Shiveluch tephras underscore the challenges of applying distal tephrochronology in volcanic regions, particularly within the fallout range of a volcanic system as 
correlations of distal and proximal tephras include analytical error and dating uncertainty, both of which may have thwarted the attribution of many of the tephras in this study.

560

561

These issues have clear implications for the ability to relate far-travelled cryptotephras to source, thus to estimate the wider environmental impact of specific eruptions, as well as to utilise the tephras as time-synchronous markers. The study of distal deposits provides a filter through which only the more widely dispersed tephras - those with the best potential for use as extra-regional isochrons - are recorded. Our work highlights the need to verify medial and distal tephra attributions though glass geochemical analysis if volcanic events and their impacts are to be reliably reconstructed. Clearly, more research in needed to tie the distal tephras securely to the proximal record, be it through an applied dating programme and/or trace and rare element analysis. Further efforts to analyse geochemically distal and proximal reference material within a common analytical session will also be beneficial for establishing robust correlations between tephras.

Acknowledgements: We are grateful to the members of the field crew who collected the lake cores as part of a Swedish Research Council grant to Keith D. Bennett (Principle Investigator), and to Elinor

574 Andrén for her assistance with the sampling of material for tephra and ${ }^{14} \mathrm{C}$ dating. Geochemical analyses were performed in Tephra Analytical Unit (TAU) in Edinburgh with funding support from the Natural Environment Research Council (UK) awarded to K.D. Bennett and S.E.C. We thank Chris Hayward for his assistance at the TAU. We are grateful to Philip Kyle for making available geochemical point data for plotting purposes, and to Florin Pendea for information about his unpublished date for the $\mathrm{KS}_{2}$ tephra. ${ }^{14} \mathrm{C}$ dates were partially funded by the ${ }^{14} \mathrm{Chrono}$ Centre, Queen's University Belfast. V.P. acknowledges support from the Otto Schmidt Laboratory and Russian Foundation for Basic Research project 13-05-00346. We are grateful to Miles Irving for 
production of Figure 2 . We thank the anonymous reviewer for very constructive comments that have helped to improve the manuscript.

\section{References}

Anderson, R., Nuhfer, E. \& Dean, W.E. 1984 Sinking of volcanic ash in uncompacted sediment in Williams Lake, Washington. Science 225, 505-508.

Andrén, E., Klimaschewski, A., Self, A.E., Andreev, A.A., Barnekow, L., Bennett, K.D., Conley, D.J., Solovieva, N., St. Amour, N.A., Edwards, T.W.D. \& Hammarlund, D. Submitted (this volume) Holocene climate and environmental change in north-eastern Kamchatka (Russian Far East). Global and Planetary Change.

Barnekow, L., Possnert, G. \& Sandgren, P. 1998 AMS ${ }^{14} \mathrm{C}$ chronologies of Holocene lake sediments in the Abisko area, northern Sweden - a comparison between dated bulk sediment and macrofossil samples. GFF 120, 59-67.

Bäumler, R. \& Zech, W. 2000 Quaternary paleosols, tephra deposits and landscape history in southern Kamchatka, Russia. Catena 41, 199-215.

Bazanova, L.I. \& Pevzner, M.M. 2001 Khangar: One more active volcano in Kamchatka. Transactions (Doklady) of the Russian Academy of Sciences, Earth Sciences 377A, 307-310.

Beierle, B. \& Bond, J. 2013 Density-induced settling of tephra through organic lake sediment. Journal of Paleolimnology 28, 433-440.

Bertrand, S., Daga, R., Bedert, R. \& Fontijn, K. 2014 Deposition of the 2011-2012 Cordón Caulle tephra (Chile, $40^{\circ} \mathrm{S}$ ) in lake sediments: Implications for tephrochronology and volcanology. Journal of Geophysical Research: Earth Surface 119, 2555-2573.

Blaauw, M., 2010 Methods and code for 'classical' age-modelling of radiocarbon sequences. Quaternary Geochronology 5, 512-518. 

equatorial East Africa. Quaternary Science Reviews 30, 3043-3059.

Braitseva, O.A., Melekestev, I.V., Ponomareva, V.V., Kirianov, V.Y., Litasova, S.N. and Sulerzhitsky, International 13/14, 177-180.

Braitseva, O.A., Melekestsev, I.V., Ponomareva, V.V. \& Sulerzhitsky, L.D. 1995 The ages of calderas, Volcanology 57, 383-402. marker layers in Kamchatka, Russia. Quaternary Research 47, 125-139. recovered from sites 881 through 884: a temporal record of Kamchatka and Kurile volcanism. In: Rea et al. (eds.), Proceedings of the Ocean Drilling Program, Scientific Results, 145, 345-381.

622 Coulter, S.E., Pilcher, J.R., Hall, V.A., Plunkett, G. \& Davies, S.M. 2010 Testing the reliability of the 623 JEOL FEGSEM 6500F electron microprobe for quantitative major element analysis of glass shards 624 from rhyolitic tephra. Boreas 39, 163-169.

Davies, S.M., Turney, C.S.M. \& Lowe, J.J. 2001 Identification and significance of a visible, basalt-rich 

Late Quaternary distal tephra-fall deposits in lacustrine sediments, Kanai Peninsula, Alaska. Quaternary Research 68, 64-78.

Deevey, E.S., Gross, M.S., Hutchinson, G.E. \& Kraybill, H.L. 1954 The natural ${ }^{14} \mathrm{C}$ content of materials from hardwater lakes. PNAS 40, 285-288. Lv Hua Hua, \& Wang, K. 2012 Characteristics and ages of tephra layers in the central Okhotsk Sea over the last 350 kyr: Deep-Sea Research, Part II, 61-64, 179-192. at Dvuh-yurtochnoe lake area, Kamchatka: Numerous landslides and lake tsunami, and their environmental impacts. Quaternary International 246, 298-311.

Dirksen, V., Dirksen, O. \& Diekmann, B. 2013 Holocene vegetation dynamics in Kamchatka, Russian Far East. Review of Palaeobotany and Palynology 190, 48-65.

Eden, D.N. \& Froggatt, P.C. 1996 A 6500-year-old history of tephra deposition recorded in the sediments of Lake Tutira, eastern North Island, New Zealand. Quaternary International 34-36, 55-64. 2014 Late Quaternary tephrostratigraphy of southern Chile and Argentina. Quaternary Science Reviews 89, 70-84.

Gehrels, M.J., Lowe, D.J., Hazell, Z.J. \& Newnham, R.M. 2006 A continuous 5300-yr Holocene cryptotephrostratigraphic record from northern New Zealand and implications for tephrochronology and volcanic hazard assessment. The Holocene 16, 173-187. 
Magnetostratigraphy and tephrochronology of the upper Quaternary sediments in the Okhotsk sea: implications of terrigenous, volcanological and biogenic matter supply. Marine Geology 183, 107129.

655

Griffiths, K., Michelutti, N., Blais, J.M., Kimpe, L.E. \& Smol, J.P. 2010 Comparing nitrogen isotopic signals between bulk sediments and invertebrate remains in High Arctic seabird-influenced ponds. Journal of Paleolimnology 44, 405-412. changes during the Holocene revealed by stable isotope records of lacustrine carbonates from Lake Igelsjön, southern Sweden. Quaternary Science Reviews 22, 353-370. A.A., Barnekow, B., and Edwards, T.W.D. Submitted (this volume) Late Holocene expansion of Siberian dwarf pine (Pinus pumila) in Kamchatka in response to increased snow cover as inferred from lacustrine oxygen-isotope records. Global and Planetary Change. Hasegawa T., Nakagawa M., Yoshimoto M., Ishizuka Y., Hirose W., Seki S., Ponomareva V. \& Rybin A. 2011 Tephrostratigraphy and petrological study of Chikurachki and Fuss volcanoes, western Paramushir Island, northern Kurile Islands: Evaluation of Holocene eruptive activity and temporal change of magma system. Quaternary International 246, 278-297.

Hunt, J.B. \& Hill, P.G. 1993 Tephra geochemistry: a discussion of some persistent analytical problems. The Holocene 3, 271-278. Jensen, B.J.L., Pyne-O’Donnell, S., Plunkett, G., Froese, D.G., Hughes, P.D.M, Sigl, M., McConnell, J.R., Amesbury, M., Blackwell, P.G., van den Bogaard, C., Buck, C., Charman, D.J., Clague, J.J., Hall, V.A., Koch, J., Mackay, H., Mallon, G., McColl, L. \& Pilcher, J.R. (2014) Transatlantic correlation of the 
675 Kyle, P.R., Ponomareva, V.V. \& Rourke Schluep, R. 2011 Geochemical characterization of marker

676 tephra layers from major Holocene eruptions in Kamchatka, Russia. International Geological Review

$67753,1059-1097$.

678

Lane, C.S., Chorn, B.T. \& Johnson, T.C. 2013 Ash from the Toba supereruption in Lake Malawi shows

679

no volcanic winter in East Africa at $75 \mathrm{ka}$. Proceedings of the National Academy of Sciences 110,

680 8025-8029.

681

Larsen, G. 1981 Tephrochronology by microprobe glass analysis. In S. Self \& R.S.J. Sparks (eds),

682

Tephra studies, D. Reidel, Dordrecht, 95-102.

683

MacDonald, G.M., Beukens, R.P. \& Kieser, W.E. 1991 Radiocarbon dating of limnic sediments: a

684 comparative analysis and discussion. Ecology 72, 1150-1155.

685

Mangerud, J., Lie, S.E., Furnes, H., Kristiansen, I.L.. \& Lømo, L. 1984 A Younger Dryas ash bed in 686 western Norway, and its possible correlations with tephra in cores from the Norwegian Sea and the North Atlantic. Quaternary Research 21, 85-104.

Melekestsev, I.V., Volynets, O.N., Ermakov, V.A., Kirsanova, T.P., Masurenkov, Y.P. 1991 Shiveluch volcano. In S.A. Fedotov \& Y.P. Masurenkov (eds), Active volcanoes of Kamchatka, vol 1. Nauka Press, Moscow, 84-103.

Newton, A.J., Metcalfe, S.E., Davies, S.J., Cook, G., Barker, P. \& Telford, R.J. 2005 Late Quaternary volcanic record from lakes of Michoacán, central Mexico. Quaternary Science Reviews 24, 91-104.

Olsson, I.U. 1979 Radiocarbon dating of material from different reservoirs. In H.E. Suess and R. Berger (eds), Radiocarbon Dating: Proceedings of the Ninth International Conference, Los Angeles and La Jolla, 1976, University of California Press, Berkeley, 613-618.

Payne, R., Blackford, J., van der Plicht, J. 2008 Using cryptotephras to extend regional 
Pevzner, M.M. 2004 The first geological data on the chronology of Holocene eruptive activity in the Ichinskii Volcano (Sredinnyi Ridge, Kamchatka). Transactions (Doklady) of the Russian Academy of Sciences/Earth Science Section 395A, 335-337.

702

Pevzner, M.M. 2010 The northern boundary of volcanic activity of Kamchatka in the Holocene.

703

Bulletin of the Kamchatka Regional Association "Educational-scientific Center". Earth Sciences 1/15,

704 117-144 [In Russian].

705

Pevzner, M.M. 2011 Spatial and temporal patterns of the volcanic activity in the Kamchatka Sredinny

Range in Holocene (according to the radiocarbon dating data) [In Russian]. Doctor of Science

Dissertation, Geological Institute, Moscow (summary available at

http://www.ginras.ru/news/files/Pevzner 2011 avt.pdf)

Ponomareva V., Portnyagin M., Derkachev A., Pendea I.F., Bourgeois J., Reimer P. J., Garbe-

Schönberg D., Krasheninnikov S., Nürnberg D. 2013a Early Holocene M 6 explosive eruption from

Plosky volcanic massif (Kamchatka) and its tephra as a link between terrestrial and marine paleoenvironmental records. International Journal of Earth Sciences 102, 1673-1699.

Ponomareva, V., Portnyagin, M., Derkachev, A., Juschus, O., Garbe-Schönberg, D. \& Nürnberg, D. 2013b Identification of a widespread Kamchatkan tephra: a middle Pleistocene tie-point between Arctic and Pacific paleoclimatic records. Geophysical Research Letters 40, 3538-3543.

Ponomareva, V.V., Kyle, P.R., Pevzner, M.M., Sulerzhitsky, L.D. \& Hartman, M. 2007 Holocene eruptive history of Shiveluch volcano. Kamchatka Peninsula. In Eichelberger, J., Gordeev, E., Kasahara, M., Izbekov, P. \& Lees, J. (eds) Volcanism and Subduction: The Kamchatka Region, American Geophysical Union Geophysical Monograph Series, American Geophysical Union, Washington DC, 172, 263-282. 
geochemical fingerprinting of volcanic glass. International Journal of Earth Science,

Pyne-O'Donnell, S.D.F. 2011 The taphonomy of Last Glacial-Interglacial transition (LGIT) distal tephra ash in small Scottish lakes. Boreas 40, 131-145.

727

Reimer, P.J., Bard, E., Bayliss, A., Beck, J.W., Blackwell, P.G., Bronk Ramsey, C., Grootes, P.M.,

Guilderson, T. P., Haflidason, H., Hajdas, I., HattŽ, C., Heaton, T.J., Hoffmann, D.L., Hogg, A.G.,

Hughen, K.A., Kaiser, K.F., Kromer, B., Manning, S.W., Niu, M., Reimer, R.W., Richards, D.A., Scott, E.

M., Southon, J.R., Staff, R., A., Turney, C.S.M. \& van der Plicht, J. 2013 IntCal13 and Marine13

radiocarbon age calibration curves 0-50,000 years cal BP. Radiocarbon 55, 1869-1887.

Savoskul, O.S. \& Zech, W. 1997 Holocene glacier advances in the Topolovaya Valley, Bystrinskiy Range, Kamchatka, Russia, dated by tephrochronology and lichenometry. Arctic and Alpine Research $29,143-155$.

Solovieva, N., Klimaschewski, A., Self, A.E., Jones, V.J., Andrén, E., Andreev, A.A., Hammarlund, D., Lepskaya, E.V. \& Nazarova, L. submitted (this volume) Holocene environmental history of a small coastal lake from north-eastern Kamchatka Peninsula. Global and Planetary Change.

Sun, C., Plunkett, G., Liu, J., Zhao, H., Sigl, M., McConnell, J.R., Pilcher, J.R., Vinther, B.M., Steffensen, J.P. \& Hall, V.A. 2014 Ash from Changbaishan Millennium eruption recorded in Greenland ice: implications for determining the eruption's timing and impact. Geophysical Research Letters 41, 694701.

Thorarinsson, S. 1967 The eruptions of Hekla in historical times. A tephrochronological study. The Eruption of Hekla 1947-1948 1, 1-170.

Volynets, O.N., Ponomareva, V.V., Braitseva, O.A., Melekestev, I.V. \& Chen, C.H. 1999 Holocene eruptive history of Ksudach volcanic massif, South Kamchatka: evolution of a large magmatic chamber. Journal of Volcanology and Geothermal Research 91, 23-42. 
747 Wohlfarth, B., Skog, G., Possnert, G. \& Holmqvist, B. 1998 Pitfalls in the AMS radiocarbon-dating of

748 terrestrial macrofossils. Journal of Quaternary Science 13, 137-145.

749 Wulf, S., Kraml, M. \& Keller, J. 2008 Towards a detailed distal tephrostratigraphy in the Central

750 Mediterranean: The last 20,000 yrs record of Lago Grande di Monticchio. Journal of Volcanology and

751 Geothermal Research 177, 118-132.

752 Wright, H.E., Jr. 1967 A square-rod piston sampler for lake sediments. Journal of Sedimentary

753 Petrology 37, 975-976.

754 Zaretskaya, N.E., Ponomareva, V.V. \& Sulerzhitsky, L.D. 2007 Radiocarbon dating of large Holocene

755 volcanic events within south Kamchatka (Russian Far East). Radiocarbon 49, 1065-1078.

756

757

758 
760

761

762

763

764

765

766

767

768

769

770

771

Fig. 1. Schematic expected tephrostratigraphy for northern (Pechora and Lifebuoy Lakes area) and central Kamchatka (Olive-backed Lake area) shown on a ${ }^{14} \mathrm{C}$ timescale, based on published tephra isopachs (Braitseva et al., 1997; Kyle et al., 2011), published sections through Holocene sediments (Pevzner, 2010, 2011; Dirksen et al., 2013), and ${ }^{14}$ C ages (Braitseva et al., 1997; Bazanova and Pevzner, 2001; Pevzner, 2004; 2010, 2011; Ponomareva et al., in press). Only half of the shown tephra layers have been geochemically analysed (Kyle et al, 2011); for others their relation to proximal tephra beds is not confirmed. Solid lines show major regional tephra layers; dashed lines show smaller tephras. Codes for tephra layers: SH - general code for all tephra layers from Shiveluch volcano; OP - Baranii Amphitheater crater (Opala volcano); KS - general code for all tephra layers from Ksudach calderas; KHG - code for tephras from Khangar volcano; SK - Svetly Kliuch crater; ICH Ichinsky volcano. Numbers after the tephra codes shown in subscript are approximate ${ }^{14} \mathrm{C}$ ages.

Fig. 2. Location of Pechora, Lifebuoy and Olive-backed lakes in Kamchatka. The locations of the main volcanoes discussed in the text and Uka Bog are also indicated.

Fig.3. Comparison of tephra glass compositions from a) Pechora Lake, b) Lifebuoy Lake, and c) Olivebacked Lake in relation to some of the main Kamchatkan volcanic systems active in the mid- to Late Holocene (fields based on geochemical data from Kyle et al., 2011, Ponomareva et al., in press). Field codes: SH - Shiveluch; OP - Opala; $\mathrm{OP}_{\mathrm{tr}}$ - Chasha Crater; $\mathrm{KS}_{1}, \mathrm{KS}_{2}, \mathrm{KS}_{3}$ - Ksudach; KHG - Khangar; KZ Kizimen; KO - Kurile Lake Crater; AV -Avachinsky crater.

Fig. 4. Schematic tephrostratigraphy and age model for Pechora Lake. The age-model was constructed using Clam version 2.2 (Blaauw, 2010) and a smooth spline of 0.1. Grey envelopes indicate the $95 \%$ error margin. ${ }^{14} \mathrm{C}$ determinations (Table 1 ) contributing to the age model are labelled to the right of the age-depth curve, and were calibrated using the Northern Hemisphere calibration curve IntCal13 (Reimer et al., 2013).

Fig. 5. Selected biplots comparing Shiveluch tephras from Pechora, Lifebuoy and Olive-backed Lakes with proximal Shiveluch units (Ponomareva et al., in press - tephras designated "SH unit") and medial data from Kyle et al. (2011: $\mathrm{SH}_{5600}$ and $\mathrm{SH}_{4700}$ recorded at Uka Bog, northern Kamchatka). 
Fig. 6. Selected biplots comparing Ksudach tephras from Pechora, Lifebuoy and Olive-backed Lakes with data from Kyle et al. (2011).

Fig. 7. Selected biplots comparing Shiveluch tephras from Pechora and Lifebuoy Lakes with proximal Shiveluch units (Ponomareva et al., in press - designated "SH unit") and distal data from Kyle et al. (2011: $\mathrm{SH}_{4700}, \mathrm{SH}_{\mathrm{dv}}, \mathrm{SH}_{3500}, \mathrm{SH}_{2}, \mathrm{SH}_{1}$ ).

Fig. 8. Schematic tephrostratigraphy and age model for Lifebuoy Lake. The age-model was constructed using Clam version 2.2 (Blaauw, 2010) and a smooth spline of 0.1. Grey envelopes indicate the $95 \%$ error margin. ${ }^{14} \mathrm{C}$ determinations (Table 1 ) and tephra attributions (including ages based on Pechora Lake tephras) contributing to the age model are labelled to the right of the agedepth curve. ${ }^{14} \mathrm{C}$ dates were calibrated using the Northern Hemisphere calibration curve IntCal13 (Reimer et al., 2013). Dates that were rejected as outliers are shown as open ${ }^{14} \mathrm{C}$ distributions.

Fig. 9. Schematic tephrostratigraphy and age model for Olive-backed Lake. The age-model was constructed using Clam version 2.2 (Blaauw, 2010) and a smooth spline of 0.1. Grey envelopes indicate the $95 \%$ error margin. Radiocarbon determinations (Table 1) and tephra attributions contributing to the age model are labelled to the right of the age-depth curve. ${ }^{14} \mathrm{C}$ dates were calibrated using the Northern Hemisphere calibration curve IntCal13 (Reimer et al., 2013). One date that was rejected as an outlier is shown as an open ${ }^{14} \mathrm{C}$ distribution.

Fig. 10. Selected biplots comparing Khangar and Opala tephras from Olive-backed Lake with data from Kyle et al. (2011): a-d) OB 592.5-594, OB 579 and OB 563a compared with proximal (98106, 98032/2, 98032/4, 98121, 99098/2) and distal (98052/1, KHG) components of the KHG tephra; e-f) OB 369 compared with proximal, medial and distal data for the OP tephra.

Fig. 11. Schematic summary of the tephrostratigraphies from Pechora, Lifebuoy and Olive-backed Lakes, shown alongside the tephrostratigraphy of Uka Bog, northern Kamchatka (Dirksen et al., 2011). Tephra designations are indicated to the left of the columns; geochemically-confirmed attributions are shown to the right (SH indicates Shiveluch origin but event uncertain). Solid lines indicate robust correlations between the sediment sequences based on geochemical attributes of 
821 well-characterised tephras. Dashed lines indicate geochemical matches between tephras whose true 822 correlations are ambiguous. 